\title{
The Role of Bulgarian Proverbs in the Modern Family
}

\author{
Manol Manolov, Ivan Stoyanov, Zlatinka Georgieva \\ Department of Psychology, "St. Cyril and St. Methodius”, University of Veliko Tarnovo, Veliko Tarnovo, Bulgaria \\ Email: manolov.manolov@gmail.com, ivan790@abv.bg, zl.georgieva@gmail.com
}

How to cite this paper: Manolov, M., Stoyanov, I. and Georgieva, Z. (2019) The Role of Bulgarian Proverbs in the Modern Family. Open Journal of Social Sciences, 7, 300-317.

https://doi.org/10.4236/jss.2019.712022

Received: November 20, 2019

Accepted: December 23, 2019

Published: December 26, 2019

Copyright $\odot 2019$ by author(s) and Scientific Research Publishing Inc. This work is licensed under the Creative Commons Attribution International License (CC BY 4.0).

http://creativecommons.org/licenses/by/4.0/ (c) (i) Open Access

\begin{abstract}
The study is funded under Contract No КП-06-M25/4 of 12.17.2018 concluded with the Research Fund of the Republic of Bulgaria. Why do we use proverbs and what do we express with them? From the perspective of social psychology, and psycholinguistics, in particular, we use them to shape our language as a basic socialiser, as well as a form through which the past is represented in the present, while the dynamics and changes shape the future. There is currently a wide range of linguistic constructs, which represent the social heritage in the context of education and attitudes transmitted from generation to generation with an aim to successfully cope with reality, to formulate the notion of living and the living itself in terms of behaviours. This report covers several areas: Social inheritance as a form of social interaction, and particularly its element of realizing the education process through proverbs; the family as a separate institution and the messages (proverbs) on family relationships passed through the generations, describing the family and its members as a function of social relations; from the perspective of the modern expectations and irrespective of which proverbs are used, the impact of proverbs on the relationships within the family is traced as a result of already established social expectations, norms, rules and attitudes accumulated for centuries and related to the right of the individual to express opinion in social life and the right to determine one's own destiny, which is often considered to be preordained; an attempt is made to represent through Bulgarian proverbs the way an individual from a functioning family interprets social reality according to their "pre-programmed" personal norms, conscience and morals.
\end{abstract}

\section{Keywords}

Psycholinguistics, Social Inheritance, Socialization, Proverbs, Family Relationships, Social Norms 


\section{Introduction}

We asked the question: "What is the influence of proverbs on young adults and do they have the same influence on parents?" or "What or who forms the identity?". According to E. Erickson's theory on psychosocial maturity and on the development of the self in the course of the life cycle, one of the factors linked to resolving the identity crisis is the stages of value orientation. The individual passes through three stages: moral, ideological and ethical. "The moral stage reflects the child's thoughts, described with absolute acceptance of authority" [1]. On the other hand, in his concept of the nine stages of identity development, in the context of the fourth and the fifth stages: "conformability" and "self-awareness", lovinger emphasises that children "... describe themselves with awareness of and continuous self-reference to the expectations of others, their values and norms of behaviour. The recognition by the reference group is highly valued and dominates the impulses" [1]. In the above stages, it seems that the only choice of the child is to accept and agree with everything that the surrounding environment provides, then to verify it during adolescence, and finally to turn it into a stable part of the self, to integrate and change reality according to these beliefs. And that is for the sake of their own safety. This seems to remain throughout their life, while realizing their self-dependence and self-reliance, the individual keeps returning to these constructs, which are permanently rooted in their mind since childhood. Naturally, the sustainability of these constructs shaped in childhood most probably depends on the parenting style. Before exploring it, we shall point out the fact that "being a specific cultural community the family keeps, develops and transmits from generation to generation of the spiritual values, norms, social habits and orientations, which ensure its normal existence in a particular social environment" [2]. At the "cognitive level, all members of the family experience needs based on norms, learned in their parental family and established in their culture. Exactly these needs express one type of attitude and behavioural stereotype for the respective parental role or another" [2]. This way and through the convergence between parents-harmonizing their style of behaviour and their perceptions, and sharing their common experience-a specific authentic system of beliefs is developed, which are by all means connected with the collective memory, but are represented through the individual style. This is the time to examine also the values, which in terms of individual consciousness are of transcendental nature. According to V. Chavdarova, being a result of the existence and interaction between social groups and communities, as well as humankind as a whole, these values constitute their subject. They exist in three forms: in the first place, values are accepted as verification of the social ideal established in the social mind and a notion of what is necessary in the different spheres of life. Secondly, the values are defined as objective manifestation of the products of social and spiritual culture. Thirdly, the social values are refracted through the individual mind and become part of the personality's psychological structure taking the form of personal values, which become source of individual motivation for 
certain behaviour [3]. This "refraction" through the individual mind should occur by means of the parenting style. In the Bulgarian reality, parenting is realized through the authoritarian style, intertwined with authoritative style. Thus, the child is given certain freedom, but this freedom is available through imperatives or orders. In other words, the freedom of personal expression is absent and the main value-the family-is placed on a pedestal, where in parents' expectations the child is seen not as a free person, but as a person that is obliged to "return the favour" of being born and raised. An evidence for that is also the meaning of life in inversion, where the parent realizes their life through the child, which is also accompanied by the attempts to predetermine the child's destiny and to shape their personality [4]. To the extent that the family also has a leading communicative function and bearing in mind the definition of the generations as communities with shared experience, the only alternative in terms of communication is "giving the right direction" to the child's life, where parents' own life experience is a crucial factor in the process of transmission through the generations [5]. It should be noted that in the case of such "national images, the collision with the unknown and the foreign has an ambivalent role-on the one hand, it is difficult to arrange new impressions in the existing system of perception and they often cause fear and sense of threat, and on the other hand, they provide an opportunity to show one's imagination and to creatively upgrade the initially accepted notion of specific objects and ideas" [6]. Nevertheless, authors assume that these images are the short cut to strengthening the ethnic and national identity, which is a prerequisite for the existence of the identity itself. If we accept the assumption that the categories applicable to the social function bear on gender, relationships, education and family, then the genetic inheritance should be given second place, after the socially acquired values, without denying its evolutionary nature.

Nevertheless, when we speak of values, perceptions of life and living in one's own interpretation, the following statements may be put forward:

- The individual, regardless of their own perceptions, has the inclination to summarise and upgrade their perceptions with short messages, which can be easily remembered, passed through the generations and reproduced in one's own living. In this sense, proverbs are the most familiar short messages, which comprise the knowledge of the past. Proverbs and idioms can be defined as the shortest construct of shared history, experience and collective memory.

- Irrespective of the width of perception and the levels of abstraction, which allow for rich or limited interpretation, and regardless of the spectrum of action related to the individual, what is of practical importance for the proverbs and idioms is to formulate behaviour with the limited categories of personal experience.

- Proverbs and idioms unfold their authentic and unique meaning depending on the relationships within the family, and while they retain their general 
substance, changes affect only those parts that are connected with the attitude to the category itself.

In his work Baba znae dve i dvesta [Grandma knows two and two hundred] Marko Semov argues that "... the folk sayings contain the complete and saturated internal life of our history and morality" [7]. Tracing the atavistic understanding of social limits in the proverbs: "The dog jumps according to the stick", "Don't feed the dog that barks at you", "Where the dog whelped, there it got its habits", etc., the dog may be considered as an animal that shall be domesticated and trained to be obedient to man. A symbolic reference may be made between the dog and the child, both should be faithful and both are "part of every house", and besides that, in terms of both national psychology and history, the status of the dog is high-“dog is man's best friend". Therefore, these proverbs are related to a form of vertical interaction and in particular to the process of upbringing.

The birth of a child satisfies a need of the parents, giving life is largely their choice (regardless of their readiness in terms of personal development, the emergence of a child is dictated by a need and has its specific function). It should be noted that the general message conveyed by these proverbs is that the child should be subordinate and to a great extent should perform as instructed. They may be arranged in the following progressive order-the idea that you learn where you are born, passing through the idea that parents dictate the rules and the "threshold of the stick", and emphasising the authority and the will of parents to go to extremes in case of disobedience. This may be assumed from the will to give up the child in case they get into something that does not conform to parents' requirements or to the norms of the environment, in which the family functions (given that the comparison with other people in the immediate social environment is deeply rooted in the Bulgarian culture). Hence the assumption that "don't feed the dog that barks at you" may be used as a preventive spell to protect the "owner of the child" from ungratefulness, and also as a sanction for failure to meet the specific expectation, which is usually imperative [4].

The nature of proverbs associated with the vertical relationships between parent and child is not only euphemistic. Development is observed also in the specific and direct messages, which are conveyed when the child has gone beyond certain limits. Then the law and the sanction are applied. Even today we can still hear adults saying proverbs with a warning and preventive purpose: "Spank the small bottom, if you don't want to spank a big one", "Bend the tree while it is young", "Break the snake's head while it is still small", "Strike while the iron is hot-no sooner, no later". These are ready linguistic structures used as pedagogical and educational models. If we direct our attention to the content of these models, we can trace the objective consequences, where neither ethical, nor moral, but physical punishment is used as a main approach. The perception is that "the child is owned by the parents", and the presumption is that they have the right to educate the child as they wish-the same however leads to breaking the personality and establishing a single personal model according 
to the expectations of parents, and the limit extends to the parent's usual environment-neighbourhood, village, building, workplace, micro group. The reality beyond this limit seems "impossible and unacceptable", it is forbidden for a child and is represented as dangerous, risky or unattainable. This originates from the district and prominent class and social boundary, which despite the declared tolerance and openness lies between the greater part of the artificially induced differences that are not normatively, legally, culturally or categorically defined. This boundary exists also between the separate classes. It may be assumed that the family is the epitome of already established social expectations, relations, norms, rules and other factors of socialization. The following proverbs may be given as a proof of this boundary: "God is high and the king is far", "We are born poor and will be buried poor", "Fear God, honour the King-and ask nothing", "The rich feel at home while abroad, and the poor feel abroad even at home". These sayings reflect the century-old attitudes towards the right to speak, the role that the individual plays in social life and in his own destiny - which is considered predetermined. This is also expressed in the attempts of parents to predetermine the life of their child [4]. Substantially, this creates an impression of an infinite distance between man and those who establish the general norms. In general, it seems that those belonging to lower classes do not deserve their personalities, hopeless and abandoned in their efforts along a worthless path, which they should not even set on because they lack confidence in their future. This may be examined also in the light of parents' desire to set the frames of their children's living, and the attempts to leave this frame are seen through the negative attitude towards things perceived as other, different, unknown, renounced as dirty and unreachable. A child that wants to do something different than what is predetermined shall be expelled. The contemporary, spontaneous messages of parents, who definitely use "no" as a main approach to education, may also be produced as evidence of the above assumptions. "Do not do this, because something bad will happen"; "Do not touch this, because it will hurt you"; "Don't laugh too much, because you will cry later". This to a certain extent sets limits for the child in obtaining their own experience. It limits the freedom of initiative and may eventually turn the child into an excellent underling and a good performer. Pointing these negative aspects out, the authors do not embrace the opposite message of removing all boundaries and of a liberal model. Rather the need for an authoritative style is emphasized, where to a certain extent the child retains control over their life within the bounds of what is safe for their health and life.

\section{Empirical Study}

In this respect, the leading idea of this study is: To examine the extent to which certain linguistic constructs (sayings) are relevant to young adults, as well as their assessment on how relevant these constructs are to their parents. We assume that social inheritance is to a great extent dependant on behaviour that is prompted by sustainable attitudes towards real phenomena that the individual 
has to cope with.

It is recognised that reality is multi-faceted and therefore may be distributed into dozens and hundreds of categories. Certainly, there are short messages regarding all of them, such as proverbs and idioms functioning as coping strategies or as short teachings in terms of the expected consequences. In order to avoid the possible eclectics, the research of social inheritance, and this research in particular, is based on the universal concept that man is destined to be social. In this sense, a selection of 130 proverbs was made, which were divided into 5 categories by means of an expert categorization made by three experts and based on agreement of $2 / 3$. The experts are two philologists and a social anthropologist. The classification criteria are directed to the extent to which these proverbs are used in the present, to what extent they are popular in literature, as well as to correspond to the categories discussed previously related to education, family, child, man and woman, relations with others. After categorizing these 130 proverbs by experts, they were collected in a questionnaire. It was provided to 210 respondents (students between 20 - 30 years of age, equally divided by gender) with the sole instruction to rate the extent to which a concept applies to them personally (Likert scale from "not applicable at all" to "fully applicable"), in order to select the most influential proverbs to be used in the actual research. This is the first group of respondents to whom the questionnaire is approbated. So after expert's evaluation and respondent's results, from these 130 proverbs, the 30 with the highest mean and are relevant to the respective categories were selected. Relevant to categories proverbs, with the highest mean were selected to fit into the actual sample (177 respondents).

The categories are as follows:

Upbringing:

- Apple doesn't fall far from the tree.

- Don't laugh too much, because you will cry later.

- Spank the small bottom, if you don't want to spank a big one.

- Break the snake's head while it is still small.

- The dog jumps according to the stick.

- Where the dog whelped, there it got its habits.

- If there is no fear, there is no shame.

Relationships with others:

- You are as good as the company you keep.

- Meek lamb sucks two mothers.

- I good heart prays to God, a naughty one bitterly cries.

- If you know how to wait, sooner or later your time will come.

- The wolf has a thick neck, because he does his job on his own.

- Each goat on her own leg stands.

Family:

- Let your son marry when you like to, and give your daughter to marriage when she is asked for. 
- He who gets married as a joke shall wear his horns.

- Make him marry to restrain his fury.

- There are two gifts we shall give our children. One is roots and the other is wings.

- If heart will allow, and hand will not allow, then nothing will follow. Man:

- Even if the man brings in with both hands full, when the woman takes out with just a little finger, the house will always be empty.

- Man is the master of the house and woman is its adornment.

- You can build a house on a father's blessing.

- A curse spoken by father may bury a son.

- Man is the head of the family and woman is its soul.

- Woman is judged by how she keeps the house, and man - by what he brings in.

Woman:

- If you don't slap a woman's neck once a week, she will not stay in the nest.

- Woman always says "Give me, husband", and never "Give me, God".

- Woman has a bag full of tears for everyone.

- Woman shall not know and say too much.

- Woman cares for a man only when she sees him.

- Woman shall be for bad and for good.

The categories have been pre-defined, because the same is established as the main axes of living in the social context. The stereotypes of man, woman, child's upbringing and relationships with others. Represented in such a way, the respective proverbs are also used to form the scales. A five-point Likert scale was used - from "not applicable at all" to "fully applicable". The respondents were asked about the extent to which a proverb applies to them and the extent to which it applies to their parents, in order to trace how attitudes are transferred from generation to generation (two levels: parents and children).

The pre-defined categories are arbitrary, and the way they are combined in the respondents' perceptions is relevant to the next hypothesis and to the planning of a long-term study.

The sample is as follows:

There were 177 respondents, which were distributed by gender, age and location as specified in Table 1.

Proverbs were used in order to avoid examining the socialization aspect and to trace instead the enculturation in interaction with experience, and respectively-the product of perception in relation to the collective unconscious.

In order to effectively trace whether the respective scales correspond to the pre-defined, a factor analysis was made, which is presented in Table 2.

The factors included in the analysis are to a great extent rearranged in the following order:

Factor 1: Imperatives, negative connotation, no expectations-woman, upbringing, family-crypt, home, fortress, nothing outside. 
Table 1. Location ${ }^{\star}$ Age $^{\star}$ Gender cross-tabulation.

\begin{tabular}{|c|c|c|c|c|c|c|c|c|}
\hline & & & & & & ge & & \\
\hline & & & & $20-25$ & $26-35$ & $36-45$ & Over 45 & \\
\hline & & & Count & 9 & 6 & 9 & 3 & 27 \\
\hline & & & $\%$ & $33.3 \%$ & $22.2 \%$ & $33.3 \%$ & $11.1 \%$ & $100.0 \%$ \\
\hline & & & Count & 0 & 3 & 0 & 0 & 3 \\
\hline & & & $\%$ & $0.0 \%$ & $100.0 \%$ & $0.0 \%$ & $0.0 \%$ & $100.0 \%$ \\
\hline & & & Count & 9 & 9 & 9 & 3 & 30 \\
\hline & & 10tal & $\%$ & $30.0 \%$ & $30.0 \%$ & $30.0 \%$ & $10.0 \%$ & $100.0 \%$ \\
\hline & & & Count & 24 & 24 & 27 & 15 & 90 \\
\hline & & District & $\%$ & $26.7 \%$ & $26.7 \%$ & $30.0 \%$ & $16.7 \%$ & $100.0 \%$ \\
\hline & & & Count & 3 & 15 & 18 & 0 & 36 \\
\hline & Location & Municipality & $\%$ & $8.3 \%$ & $41.7 \%$ & $50.0 \%$ & $0.0 \%$ & $100.0 \%$ \\
\hline & & & Count & 6 & 9 & 6 & 0 & 21 \\
\hline & & & $\%$ & $28.6 \%$ & $42.9 \%$ & $28.6 \%$ & $0.0 \%$ & $100.0 \%$ \\
\hline & & & Count & 33 & 48 & 51 & 15 & 147 \\
\hline & & 1otal & $\%$ & $22.4 \%$ & $32.7 \%$ & $34.7 \%$ & $10.2 \%$ & $100.0 \%$ \\
\hline
\end{tabular}

A sample of 177 respondents.

Table 2. Rotated component matrix.

\begin{tabular}{|c|c|c|c|c|c|}
\hline & \multicolumn{5}{|c|}{ Component } \\
\hline & 1 & 2 & 3 & 4 & 5 \\
\hline v1 & 0.616 & & & & \\
\hline $\mathrm{v} 2$ & & & & 0.452 & \\
\hline v3 & 0.702 & & & & \\
\hline $\mathrm{v} 4$ & & & & 0.460 & \\
\hline v5 & 0.779 & & & & \\
\hline v6 & & & & 0.602 & 0.532 \\
\hline v7 & & & & & 0.788 \\
\hline v8 & & 0.539 & & 0.495 & \\
\hline v9 & & 0.596 & & & \\
\hline v10 & 0.664 & & & & \\
\hline v11 & 0.762 & & & & \\
\hline v12 & & 0.616 & & & \\
\hline v13 & 0.734 & & & & \\
\hline v14 & & 0.589 & & & \\
\hline v15 & & & 0.541 & 0.612 & \\
\hline v16 & & & 0.653 & & \\
\hline v17 & & 0.657 & & & \\
\hline
\end{tabular}




\section{Continued}

\begin{tabular}{lllll}
\hline v18 & & 0.765 & & \\
v19 & & & 0.485 \\
v20 & 0.661 & & 0.410 \\
v21 & & 0.593 & \\
v22 & & 0.743 & \\
v23 & & 0.589 & 0.435 & \\
v24 & 0.487 & 0.524 & \\
v25 & 0.446 & 0.450 & \\
v26 & & 0.648 & \\
v27 & & 0.640 & \\
v28 & & & 0.485 \\
v29 & & & \\
v30 & & & \\
\end{tabular}

Extraction Method: Principal Component Analysis. Rotation Method: Varimax with Kaiser Normalization. a. Rotation converged in 10 iterations.

- If you don't slap a woman's neck once a week, she will not stay in the nest.

- Spank the small bottom, if you don't want to spank a big one.

- Make him marry to restrain his fury.

- Let your son marry when you like to, and give your daughter to marriage when she is asked for.

- Woman always says "Give me, husband", and never "Give me, God".

- Apple doesn't fall far from the tree.

Factor 2: Limits, woman-man, family, relationships (upbringing not included).

Positive connotation. Message "I don't care about the child" man-woman relationships.

- There are two gifts we shall give our children. One is roots and the other is wings.

- If you know how to wait, sooner or later your time will come.

- I good heart prays to God, a naughty one bitterly cries.

- Man is the master of the house and woman is its adornment.

- Woman shall be for bad and for good.

- If heart will allow, and hand will not allow, then nothing will follow.

- You can build a house on a father's blessing.

Factor 3: Relationships with others, upbringing, man-woman (family not included) individualism, limits, imperative. Traditionalism, patriarchy.

- The wolf has a thick neck, because he does his job on his own.

- Break the snake's head while it is still small.

- Where the dog whelped, there it got its habits.

- If there is no fear, there is no shame.

- The dog jumps according to the stick. 
- Man is the head of the family and woman is its soul.

- Woman cares for a man only when she sees him.

Factor 4: Woman-man, family relationships (upbringing not included). Individualism, patriarchy, negative connotation.

- Woman has a bag full of tears for everyone.

- He who was married as a joke shall wear his horns.

- Each goat on her own leg stands.

- A curse spoken by father may bury a son.

- Even if the man brings in with both hands full, when the woman takes out with just a little finger, the house will always be empty.

- You are as good as the company you keep.

- Woman shall not know and say too much.

Factor 5: Upbringing, relationships, man-limits, patience.

- Don't laugh too much, because you will cry later.

- Meek lamb sucks two mothers.

- Woman is judged by how she keeps the house, and man-by what he brings in.

The factors are distributed in the form of scenarios.

The new factors formed are expected to make a difference in the respondents' overall perception and assessment of their parents. The received factors are considered as authentic, especially for the respondents, which creates the likelihood that the statistically significant difference between them and their parents is obtained in this arrangement. Identifying these differences is the reason for applying the appropriate statistical method. The paired samples T-Test is presented in Table 3, which represents a distribution of the proverbs according to the factors established after the factor analysis and the specific differences in the perception of "me-my parents".

In all factors there are noticeable differences between the respondents and their parents, where the values for the respondents are lower than those for their parents. This is most obvious for the first and the fifth factor. The difference is less notable in the second factor, which can be definitely viewed also as the only one with positive connotation based on the variables it contains.

Table 3. Paired samples test.

\begin{tabular}{|c|c|c|c|c|c|c|c|c|c|}
\hline & & \multicolumn{5}{|c|}{ Paired Differences } & \multirow{3}{*}{$\mathrm{t}$} & \multirow{3}{*}{ df } & \multirow{3}{*}{$\begin{array}{c}\text { Sig. } \\
\text { (2-tailed) }\end{array}$} \\
\hline & & \multirow{2}{*}{ Mean } & \multirow{2}{*}{ Std. Deviation } & \multirow{2}{*}{ Std. Error Mean - } & \multicolumn{2}{|c|}{$95 \%$ Confidence Interval of the Difference } & & & \\
\hline & & & & & Lower & Upper & & & \\
\hline Pair 1 & MeF1 - ParF1 & -0.71751 & 0.88368 & 0.11505 & -0.94780 & -0.48723 & -6.237 & 58 & 0.000 \\
\hline Pair 2 & $\mathrm{MeF} 2$ - ParF2 & -0.15496 & 0.54900 & 0.07147 & -0.29803 & -0.01189 & -2.168 & 58 & 0.034 \\
\hline Pair 3 & MeF3 - ParF3 & -0.55690 & 0.83876 & 0.10920 & -0.77548 & -0.33832 & -5.100 & 58 & 0.000 \\
\hline Pair 4 & $\mathrm{MeF} 4$ - ParF4 & -0.53995 & 0.69687 & 0.09072 & -0.72156 & -0.35835 & -5.952 & 58 & 0.000 \\
\hline Pair 5 & MeF5 - ParF5 & -0.75141 & 0.87009 & 0.11328 & -0.97816 & -0.52466 & -6.633 & 58 & 0.000 \\
\hline
\end{tabular}


In general, the factor that is most relevant to the respondents is the second one, followed by the third, the fifth, the fourth and the first.

The age and the location do not have any influence on the weight of factors.

The variables in Figure 1 are arranged in clusters and the dendrogram shows two stable clusters:

In the first cluster, most tightly connected are the variables related to man, upbringing and attitude to others. If related specifically to upbringing, it includes the proverbs on limits and early education, presence of fear and authoritarian attitude. When related to the relationships with others, it includes individuality, patience and the metamorphoses of submissiveness. Family is related to the roots, the importance of the family (if the relationship is not serious, then horns will appear ...), as well as with man's figure that shall provide sustenance. The values associated with the woman are related to the likelihood to "betray" the man.

Predominant in the second cluster is the feminine element, which is related to the other aspects in the following way: the importance of establishing a family, the marriage of the son to restrain his rage (to soothe his temper), in relation to upbringing it is presented as a milder version of early education "small bottom", as well as the forms of social transmission in "Apple doesn't fall far from the tree", together with the limits. As regards the relationship with others-a mild form of individualism, meekness and "social alignment". Limits, early acquired fear and expected similarity with father or mother are the main expectations related to upbringing. The child should be like their parents, shall fear them and shall be reasonable, quiet and obedient.

Based on the obtained results, the following assumptions may be construed: If

\begin{tabular}{|c|}
\hline $\begin{array}{l}\text { Dendrogram using Complete Linkage } \\
\text { Rescaled Distance Cluster Combine }\end{array}$ \\
\hline Woman always says "Give me, husband", and never "Give me, God". \\
\hline Woman cares for a man only when she sees him. \\
\hline Where the dog whelped, there it got its habits. \\
\hline You can build a house on a father's blessing. \\
\hline If heart will allow, and hand will not allow, then nothing will follow. \\
\hline Man is the master of the house and woman is its adornment. \\
\hline Man is the head of the family and woman is its soul. \\
\hline I good heart prays to God, a naughty one bitterly cries. \\
\hline A curse spoken by father may bury a son. \\
\hline The dog jumps according to the stick. \\
\hline Woman is judged by how she keeps the house, and man - by what he brings in. \\
\hline Break the snake's head while it is still small. \\
\hline If there is no fear, there is no shame. \\
\hline The wolf has a thick neck, because he does his job on his own. \\
\hline $\begin{array}{l}\text { If you know how to wait, sooner or later your time will come. } \\
\text { There are two gifts we shall give our children. }\end{array}$ \\
\hline One is roots and the other is wings. \\
\hline He who gets married as a joke shall wear his horns. \\
\hline Woman shall be for bad and for good. \\
\hline $\begin{array}{l}\text { Let your son marry when you like to, and give your daughter to marriage when she is } \\
\text { asked for. }\end{array}$ \\
\hline Woman shall not know and say too much. \\
\hline If you don't slap a woman's neck once a week, she will not stay in the nest. \\
\hline Make him marry to restrain his fury. \\
\hline Spank the small bottom, if you don't want to spank a big one. \\
\hline Apple doesn't fall far from the tree. \\
\hline Don't laugh too much, because you will cry later. \\
\hline Meek lamb sucks two mothers. \\
\hline Woman has a bag full of tears for everyone. \\
\hline Each goat on her own leg stands. \\
\hline You are as good as the company you keep. \\
\hline $\begin{array}{l}\text { Even if the man brings in with both hands full, when the woman takes out with just a } \\
\text { little finger, the house will always be empty. }\end{array}$ \\
\hline
\end{tabular}

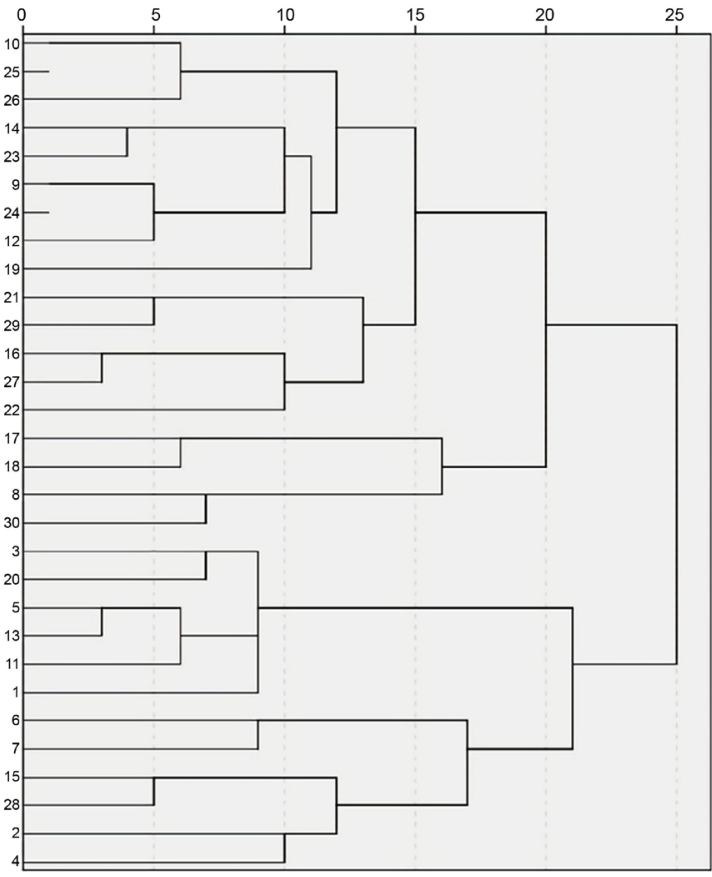

Figure 1. Dendrogram clusters. 
the expected results from education in the modern conditions are not achieved, should this be attributed to the fact that in the matriarchy, the mother is the main pillar of the home and the family values, as well as the main authority. In this regard, the question that arises is about the level to which the authority of the contemporary mother extends. Since in the third factor the family element is absent in the relationships between man and woman, the roles are turned around where the father is the leading authoritative figure, education is his "responsibility", and from a global point of view he shall educate not only the children, but also the woman (his wife), which is illustrated in the proverb "If you don't slap a woman's neck once a week, she will not stay in the nest" or "Woman is judged by how she keeps the house, and man-by what he brings in". In the last proverb, the used wording judged by how she keeps the house means that here the woman is not expected to be just an adornment, but to have learned or to learn how to run the housework, to take care of the children and so on. On the other hand, in the proverb "Man is the master of the house and woman is its adornment", the woman is the jewel of the home. Hence, there is a contradiction-we can use it only when the positive relationships between the man and the woman are as in "If heart will allow, and hand will not allow, then nothing will follow." Probably the only proverb included in Table 4, which can be separated in meaning from the others is "If you know how to wait, sooner or later your time will come", and it is related to the role of the child, who in the contemporary times cannot clearly differentiate between the parental roles, and more precisely which parent is assigned with the educational role. The same is valid also for the attitude and the educational role in society (the family believes education is responsibility of the institutions and vice versa). So the child is placed in a waiting position, they delay taking a decision, although they are ready for that.

In this regard, after the above proverbs were clustered and ranked according to the extent to which they were applicable to the students themselves and to their parents, the results are as presented in Table 5 and Table 6 (two tables about more visibility), as follows: For the respondents-the students, most important are the proverbs related to family, positive upbringing and preserving the roots, as well as the individualistic and the gender stereotypes, which are associated with equal standing of men and women, provided that the roles in the family are preserved. In this sense, we can consider the fact that patience is emphasized, but in terms of weight it is placed after the individualistic. The notion of knowing the limits implied in "jumping according to the stick" is present in the ten most significant proverbs, as well as the inheritance associated with the notion that kinship has a certain weight in character formation.

Table 4. Relevant to respondents factors.

\begin{tabular}{cccccc}
\hline & MeF1 & MeF2 & MeF3 & MeF4 & MeF5 \\
\hline Mean & 2.2514 & 3.3705 & 3.0436 & 2.4891 & 2.6384 \\
Std. Deviation & 1.00781 & 0.98801 & 1.05555 & 0.89537 & 1.09210 \\
\hline
\end{tabular}


Table 5. Students.

\begin{tabular}{|c|c|c|}
\hline Proverbs & Mean & Std. Deviation \\
\hline $\begin{array}{l}\text { There are two gifts we shall give our children. One is roots and the } \\
\text { other is wings. }\end{array}$ & 4.3390 & 1.24027 \\
\hline The wolf has a thick neck, because he does his job on his own. & 3.8136 & 1.33229 \\
\hline Man is the head of the family and woman is its soul. & 3.5932 & 1.48694 \\
\hline If you know how to wait, sooner or later your time will come. & 3.5932 & 1.36607 \\
\hline The dog jumps according to the stick. & 3.5593 & 1.52305 \\
\hline Woman shall be for bad and for good. & 3.4915 & 1.43085 \\
\hline Apple doesn' $t$ fall far from the tree. & 3.3051 & 1.34234 \\
\hline If heart will allow, and hand will not allow, then nothing will follow. & 3.2034 & 1.50608 \\
\hline You can build a house on a father's blessing. & 2.9153 & 1.45375 \\
\hline Where the dog whelped, there it got its habits. & 2.8983 & 1.44670 \\
\hline Don't laugh too much, because you will cry later. & 2.8644 & 1.54761 \\
\hline I good heart prays to God, a naughty one bitterly cries. & 2.8475 & 1.48340 \\
\hline If there is no fear, there is no shame. & 2.8136 & 1.47945 \\
\hline Man is the master of the house and woman is its adornment. & 2.8136 & 1.45596 \\
\hline You are as good as the company you keep. & 2.7797 & 1.39046 \\
\hline A curse spoken by father may bury a son. & 2.7458 & 1.43351 \\
\hline Woman has a bag full of tears for everyone. & 2.6949 & 1.54534 \\
\hline $\begin{array}{l}\text { Woman is judged by how she keeps the house, and man - by what he } \\
\text { brings in. }\end{array}$ & 2.6949 & 1.41731 \\
\hline He who was married as a joke shall wear his horns. & 2.6610 & 1.52689 \\
\hline Break the snake's head while it is still small. & 2.6441 & 1.49439 \\
\hline Each goat on her own leg stands. & 2.5254 & 1.41855 \\
\hline Spank the small bottom, if you don't want to spank a big one. & 2.4407 & 1.48871 \\
\hline Woman cares for a man only when she sees him. & 2.3729 & 1.40072 \\
\hline Meek lamb sucks two mothers. & 2.3559 & 1.28335 \\
\hline $\begin{array}{l}\text { Even if the man brings in with both hands full, when the woman takes } \\
\text { out with just a little finger, the house will always be empty. }\end{array}$ & 2.3220 & 1.35749 \\
\hline Woman always says "Give me, husband", and never" Give me, God". & 2.0847 & 1.29039 \\
\hline $\begin{array}{l}\text { Let your son marry when you like to, and give your daughter to } \\
\text { marriage when she is asked for. }\end{array}$ & 2.0339 & 1.40155 \\
\hline Make him marry to restrain his fury. & 1.8475 & 1.12669 \\
\hline $\begin{array}{l}\text { If you don't slap a woman's neck once a week, she will not stay in the } \\
\text { nest. }\end{array}$ & 1.7966 & 1.31017 \\
\hline Woman shall not know and say too much. & 1.6949 & 1.19271 \\
\hline
\end{tabular}

Regarding the answers given about the parents: We can conclude that in general, the fundamental values that the students presumed about their parents are associated with setting the limits, upbringing, preserving the roots and similarity 
Table 6. Parents.

\begin{tabular}{|c|c|c|}
\hline Proverbs & Mean & Std. Deviation \\
\hline The dog jumps according to the stick. & 4.2373 & 1.23650 \\
\hline Apple doesn't fall far from the tree. & 4.1186 & 1.11548 \\
\hline The wolf has a thick neck, because he does his job on his own. & 4.0847 & 1.17866 \\
\hline If you know how to wait, sooner or later your time will come. & 3.9661 & 1.23129 \\
\hline Woman shall be for bad and for good. & 3.8136 & 1.37056 \\
\hline $\begin{array}{l}\text { There are two gifts we shall give our children. One is roots and the } \\
\text { other is wings. }\end{array}$ & 3.7458 & 1.40925 \\
\hline You are as good as the company you keep. & 3.6441 & 1.39905 \\
\hline You can build a house on a father's blessing. & 3.6102 & 1.37737 \\
\hline Spank the small bottom, if you don't want to spank a big one. & 3.5763 & 1.49946 \\
\hline Don't laugh too much, because you will cry later. & 3.5593 & 1.31662 \\
\hline Man is the head of the family and woman is its soul. & 3.5593 & 1.36800 \\
\hline $\begin{array}{l}\text { Woman is judged by how she keeps the house, and man - by what he } \\
\text { brings in. }\end{array}$ & 3.5424 & 1.45415 \\
\hline Where the dog whelped, there it got its habits. & 3.5424 & 1.30413 \\
\hline Break the snake's head while it is still small. & 3.4746 & 1.52401 \\
\hline If heart will allow, and hand will not allow, then nothing will follow. & 3.4237 & 1.48792 \\
\hline If there is no fear, there is no shame. & 3.4068 & 1.48694 \\
\hline A curse spoken by father may bury a son. & 3.1186 & 1.52094 \\
\hline Each goat on her own leg stands. & 3.0847 & 1.42983 \\
\hline Meek lamb sucks two mothers. & 3.0678 & 1.48399 \\
\hline I good heart prays to God, a naughty one bitterly cries. & 3.0678 & 1.42471 \\
\hline Man is the master of the house and woman is its adornment. & 3.0508 & 1.50200 \\
\hline Woman has a bag full of tears for everyone. & 2.9831 & 1.46795 \\
\hline He who was married as a joke shall wear his horns. & 2.9322 & 1.65950 \\
\hline Woman cares for a man only when she sees him. & 2.8983 & 1.50511 \\
\hline $\begin{array}{l}\text { Let your son marry when you like to, and give your daughter to } \\
\text { marriage when she is asked for. }\end{array}$ & 2.8305 & 1.49888 \\
\hline $\begin{array}{l}\text { Even if the man brings in with both hands full, when the woman takes } \\
\text { out with just a little finger, the house will always be empty. }\end{array}$ & 2.8136 & 1.58086 \\
\hline Make him marry to restrain his fury. & 2.6610 & 1.42163 \\
\hline Woman shall not know and say too much. & 2.6271 & 1.65985 \\
\hline Woman always says "Give me, husband", and never" Give me, God". & 2.4915 & 1.48988 \\
\hline $\begin{array}{l}\text { If you don't slap a woman's neck once a week, she will not stay in the } \\
\text { nest. }\end{array}$ & 2.1356 & 1.40759 \\
\hline
\end{tabular}

between child and parents, as well as patience. The underlying likening of the individual to the influence of the environment is quite intensive and it seems to be conditioned by the patriarchal element, distributed between the traditional 
family and the authoritarian and authoritative style prevailing in the Bulgarian sample (Stoyanov and Manolov, 2018).

The role stereotypes based on gender are pushed to the background. Noticeable is the presence of the proverb "If you know how to wait, sooner or later your time will come" at the fourth place. It reveals the preserved peaceable disposition and kindness interwoven in the generation. The lack of aggression in people (Semov, 1985). This however shall be clearly distinguished from the bowed head and the obedience. Moreover, this is a niche that poses challenges since it is preserved, but insufficiently studied-the peaceable disposition, which is intertwined with the inclination to quickly fire up when the most precious is violated. Although this may be seen as a paradox in the character, it would be bold to express it in such a way in view of the generational evolution and the more likely positivism emanating from the preferences in the context of the collective unconscious. This may also be referred to the parents Table 6 , and hence it may be assumed that meekness and submissiveness remain in the background and are replaced by peaceable disposition, indecisiveness and possibly by stable roots in the traditional and patriarchal.

The family remains an intensely represented value in the context of a two-level study of the presumptions of students about their parents. The authoritarian education has remained part of family upbringing for the majority of students, and it is perfectly logical to remain in the second half of the ranking of their preferences. It is no surprise that there are significant statistical differences for the mentioned factors (first and fifth) associated with imperatives, limits and patience. The main value is still the family, which carries the nuances of the traditional, but it is accompanied in the first place by the knowledge about the roots and the freedom of the child to dream, rather than by the strict and imperative upbringing. The belief that character is predetermined by the way of life is more than strongly emphasized, as well as the recurrence of the way of life, which is introduced "as the only criterion to determine many of the human qualities" [7]. This applies also to the respondents themselves. Both in the self-assessment and the assessment of their parents, the possibility that external factors may also shape the individual is also admitted by "You are as good as the company you keep". And it seems that parents have better discerned these two possibilities, which the respondents themselves have placed lower in the their "list" of agreement.

The distribution of the proverbs in two clusters is also an interesting result regarding both categories, which actually differentiate the two aspects. If a general conclusion should be made in this regard, then the main difference and change in the conditions of transmission between the generations are associated with preserving the values at a lower level of authoritarianism and finding the balance in the gender and role model of the family. This does not alter the overall picture of the collective unconscious also because in the national psychology the respect to women has never been denied, neither in the family, nor in society, in view of the absence of a definite ban or limitation of the equal access 
(based on gender) for men and women to the various institutions. The assessment element there is also obvious: The first saying for instance, "The dog jumps according to the stick", warns us about the dependence of people on adverse circumstances [8]. Hence the respective culturemes are as follows: "the dependence of people on adverse circumstances (-)", "existence of a way out of a difficult situation $(+)$ " and "reducing the needs and expenses when necessary $(+)$ ". It is obvious that the key to revealing the cultural essence of parables is on the pragmatic level-in the proverbs. Moreover, Semov emphasizes that the stick, devoid of meaning and sense, is raised to the level of a social limit that has "accumulated the whole national feeling of a terrible, irrevocable reality" [7]. It is also associated with the predestined reality of the limits, which the way of life forces to the mind.

Overall, except the meaning attached to the general, the distinction in the categories of proverbs may definitely be added as a conclusion. The first cluster that has formed refers to authoritarianism, individualism and submissiveness, while in the second one, the stable family is most prominent and has not been washed away as a value in the Bulgarian society. The differentiation of the two clusters to a great extent represents also the differences between the generations, where in the family styles (adding the authoritative) the softer messages are underlined, aimed at "restraining the rage", while "breaking" and the authoritarian is not prominent. This is confirmed also by the presumptions given in relation to limits, rough education, roots and patience. On the other hand, the students have given second place to the role stereotypes based on gender. The sustained peaceable disposition and kindness interwoven in the generation are also revealed. The lack of aggression in people. The family, bearing the nuances of the traditional, is preserved as a fundamental value. The authoritarian education is not relevant. It is no surprise that there are significant statistical differences for the mentioned factors (first and fifth) associated with imperatives, limits and patience.

In this sense, the outline provides an insight about the collective memory and its alterations. This may also provide answers to the question whether the broader research of social inheritance should rely on methods related to the specific attitudes to particular constructs.

\section{Conclusions}

In conclusion, there is a possible statement about sustainability in relation to the attitudes conveyed through short messages (proverbs) regarding the constructs of reality that are related to the social nature of man. Without denying or leaving behind the biologically determined and evolutionary, it is inferred that, although differently distributed, there is no clear boundary with regard to short messages. In this sense, parental influence and social inheritance in the context of the factors considered are sustainable insofar as certain "beliefs" acquire a lower value for the respondents, which can be seen in the context of cultural dynamics. 
However, it is of interest to re-categorize the proverbs from the predefined ones in folklore. This reformulation essentially makes it possible to derive meaningful cultural dynamics. In particular, the same categories transmitted over time are intertwined differently in the context of family relationships. This can also be seen as the most significant conclusion of the present work-the reformulation of the same categories as participating and forming different factors. In other words, the social attitude transmitted by the proverbs continues to exist, but is formed as a real attitude in the face of the externally imposed social reality (political, cultural, global), which does not essentially change the existing attitude, but put it into a factor which is relevant to social demand.

The main contributions of this study are:

- social inheritance between two generations (adults) in relation to social functioning changes substantially while maintaining similar linguistic concepts;

- the categories of relativity of concepts change, creating new perceptions of the family, gender-based attitudes, upbringing and relationships;

- probably the old contents in the new layout would give behavioral reflections, which will be explored with the following methodology presented.

Limitations of the present work are the impossibility of both a larger sample and the inability to evaluate parents for their perceptions of their children, and impossibility for evaluation of their behaviour to next generation. Either way, the respondents are merely a direction for conceptualizing social inheritance. The final survey on the resulting orientation is coming in the next few months. It is planned to consider social inheritance through WIPPF for parents and IBQ for children, possibly a direct specialist assessment of the child through Denver II. The expectation that a response will be received in relation to how a conflict, the presence of a characteristic in parents, reflects on the temperament of the child, respectively, in the manifestation of some of its peculiarities.

\section{Conflicts of Interest}

The authors declare no conflicts of interest regarding the publication of this paper.

\section{References}

[1] Bakracheva, M. (2009) Identity in Three Steps. Sofia. Paradigm. (In Bulgarian)

[2] Tasevska, D. (2008) SOS Families in Crisis. Psychological and Effective Parenting Support to Dysfunctional Families. V. Tarnovo. St. Cyril and St. Methodius University Press, Veliko Tarnovo. (In Bulgarian)

[3] Chavdarova, V. (2018) Cross-Cultural Aspects of the Carrier Choice. V. Tarnovo. St. Cyril and St. Methodius University Press, Veliko Tarnovo. (In Bulgarian)

[4] Stoyanov, I. and Manolov, M. (2018) Psychology of Parental Styles in the Field of Meaning in Life. V. Tarnovo. St. Cyril and St. Methodius University Press, Veliko Tarnovo.

[5] Sanko, C. (2016) Communication, Generation and Cultural Memory: Insights from Fieldwork in Vietnam. In: Politics, Civil Society and Participation: Media and 
Communications in a Transforming Environment, edition lumière, Bremen, 213-226.

[6] Stoyanova-Encheva, O. (2018) Europe and the Islam. Interreligious and Interethnic Influence in the Process of European Integration. In: Europe at a Crossroads West Balkans, Veliko Tarnovo European Information Centre, 222-239. (In Bulgarian)

[7] Semov. M. (1985) Grandma Knows Two and Two Hundred. Georgi H. Danov. Plovdiv. (In Bulgarian)

[8] Petrova, R. (2013) Bulgarian Proverbs Used for Mockery and Praise (A Linguocultural Study). Language and Culture Series. Ruse. (In Bulgarian) 